\title{
COMPARATION OF PHENOTYPIC AND GENOTYPIC PROFILE OF CARBAPENEMASE PRODUCING Escherichia coli
}

\author{
Silvia Sutandhio ${ }^{1}$, Budiono $^{2}$, Hardiono $^{3}$, Kuntaman $^{4}$, Eddy Bagus Wasito $^{4}$, Maria Inge Lusida ${ }^{4,5}$ \\ ${ }^{1}$ Faculty of Medicine, Widya Mandala Catholic University, ${ }^{2}$ Department of Public Health and Preventive Medicine, \\ Faculty of Medicine, Universitas Airlangga, ${ }^{3}$ Department of Anaesthesiology and Reanimation, ${ }^{4}$ Department of Clinical \\ Microbiology, Faculty of Medicine of Universitas Airlangga, Dr. Soetomo Hospital, ${ }^{5}$ Institute of Tropical Disease, \\ Universitas Airlangga, Surabaya.
}

\begin{abstract}
ABSTRAK
Escherichia coli (E. coli) yang memproduksi karbapenemase menyebabkan masalah pada pemilihan antibiotik terapeutik. Prosedur penyaringan karbapenemase di laboratorium biasanya didasarkan pada sistem semi otomatis yang tidak akurat. Konfirmasi dan klasifikasi karbapenemase menurut Ambler dapat dilakukan dengan kombinasi metode fenotipik, yaitu Modified Hodge Test (MHT), Sodium Mercaptoacetic Acid (SMA), dan 3-Aminophenylboronic Acid (PBA). Penelitian ini bertujuan untuk membandingkan profil E. coli penghasil karbapenemase yang dikonfirmasi dan diklasifikasikan secara fenotipik dengan profil genotipik. Isolat E. coli dari spesimen urin yang potensial sebagai produsen karbapenemase menurut sistem semi otomatis BD Phoenix diuji secara fenotipik dengan MHT, SMA, dan PBA. Isolat dikelompokkan sebagai produsen karbapenemase dan produsen non karbapenemase. Isolat produsen karbapenemase fenotipik dikelompokkan berdasarkan kriteria Ambler. Semua isolat kemudian diuji dengan Polymerase Chain Reaction (PCR) untuk mengetahui gen OXA-48, IMP1, IMP2, GES, VIM, NDM, KPC. Dari 30 isolat, 6 isolat (20,0\%) adalah MHT positif, dan 25 isolat (83,3\%) adalah SMA positif, yang menunjukkan bahwa kebanyakan isolat yang dihasilkan adalah karbapenemase Ambler B. PCR mengkonfirmasi 12 isolat (40,0\%) telah Gen VIM yang diklasifikasikan sebagai karbapenemase Ambler B. Uji konfirmasi fenotipik memiliki sensitivitas 100\% dan kekhususan 22,2\%. Klasifikasi dengan uji konfirmasi fenotipik memiliki 91,7\% kecocokan dengan PCR. Uji konfirmasi fenotipik mendeteksi lebih banyak karbapenemase dibandingkan PCR. Spesifisitas rendah ini mungkin disebabkan oleh penggunaan standar diagnostik emas yang tidak tepat. PCR tidak boleh digunakan untuk konfirmasi karbapenemase rutin karena keragaman karbapenemase yang luas. Uji konfirmasi phenotip dapat mengklasifikasikan karbapenemase sesuai klasifikasi Ambler. (FMI 2018;54:10-15)
\end{abstract}

Kata kunci: Escherichia coli; karbapenemase; fenotipik; genotipik

\begin{abstract}
Carbapenemase-producing Escherichia coli (E. coli) has caused trouble in therapeutic antibiotic selection. Carbapenemase screening procedure in laboratories is usually based on inacurate semi-automatic system. Confirmation and classification of carbapenemases according to Ambler can be done with combination of phenotypic methods, i.e., Modified Hodge Test (MHT), Sodium Mercaptoacetic Acid (SMA), and 3-Aminophenylboronic Acid (PBA). This study aimed to compare profiles of carbapenemase-producing E. coli which were confirmed and classified phenotypically with the genotypic profiles. E. coli isolates from urine specimens which were potential as carbapenemase-producers according to semi-automatic system BD Phoenix were phenotypically tested with MHT, SMA, and PBA. Isolates were grouped as carbapenemase-producers and non carbapenemaseproducers. Phenotypic carbapenemase-producer isolates were classified based on Ambler criteria. All isolates were then tested with Polymerase Chain Reaction (PCR) for the presence of OXA-48, IMP1, IMP2, GES, VIM, NDM, KPC genes. Out of 30 isolates, 6 isolates (20.0\%) were MHT positive, and 25 isolates (83.3\%) were SMA positive, which indicated that most isolates produced were carbapenemase Ambler B. PCR confirmed 12 isolates (40.0\%) had VIM gene which were classified as carbapenemase Ambler B. Phenotypic confirmatory test had $100 \%$ sensitivity and $22.2 \%$ specificity. Classification with phenotypic confirmatory test had $91.7 \%$ match with PCR. Phenotypic confirmatory test detected more carbapenemase than PCR. This low specificity may be caused by inappropriate use of diagnostic gold standard. PCR should not be used for routine carbapenemase confirmation because of vast diversity of carbapenemases. Phenotypic confirmatory test can classify carbapenemase according to Ambler classification. (FMI 2018;54:10-15)
\end{abstract}

Keywords: Escherichia coli; carbapenemase; phenotypic; genotypic

Correspondence: Maria Inge Lusida, Institute of Tropical Disease, Universitas Airlangga Campus C, Mulyorejo, Surabaya. Email: ingelusida@yahoo.com

\section{INTRODUCTION}

In the last 15 years, specific concerns have been addressed to bacterial resistance to antibiotics, particu- larly broad spectrum antibiotics. The use of carbapenem, which is the drug of choice to eradicate pathogenic Extended Spectrum $\beta$-Lactamase (ESBL) producer 
Gram-negative bacteria, was quickly followed by evolution of carbapenemase-producer bacteria strains (Tängdén 2012).

Escherichia coli $(E$. coli) is the most frequent bacteria found in urine specimens. Over $50 \%$ of E. coli isolates obtained from patients in Dr. Soetomo Hospital, Surabaya, produced ESBL. Whereas, carbapenemaseproducer $E$. coli has not been confirmed according to procedure recommended by Clinical and Laboratory Standards Institute (CLSI) 2016 (Sutandhio et al 2015, CLSI 2016).

Carbapenemase screening in clinical microbiology laboratory uses semi-automatic BD Phoenix system, which gives inaccurate results. This may lead to confusion and excessive cautions (Woodford et al 2010, CLSI 2016). Phenotypic carbapenemase confirmatory test is a combination of Modified Hodge Test (MHT), Sodium Mercaptoacetic Acid (SMA), and 3-Aminophenylboronic Acid (PBA). Phenotypic confirmatory test is expected to detect carbapenemases better than BD Phoenix system, and to classify the enzymes based on Ambler classification (Kim et al 2007, EUCAST 2013, CLSI 2016).

Ambler classified carbapenemases into three classes; A, $\mathrm{B}$, and D. In class A, carbapenemases are mostly produced by Enterobacteriaceae. In class B, carbapenemases are metallo- $\beta$-lactamase (MBL) which are mostly produced by Pseudomonas aeruginosa, Enterobacteriaceae, and Acinetobacter baumannii. Whereas, in class D, carbapenemases are produced by Acinetobacter spp., and in some cases, by Pseudomonas aeruginosa, Klebsiella pneumoniae, and E. coli (Queenan \& Bush 2007, Thomson 2010).

\section{MATERIALS AND METHODS}

$E$. coli isolates from urine specimens that were potential carbapenemase-producers according to $\mathrm{BD}$ Phoenix semi-automatic system during six weeks period (23 August 2016 - 4 October 2016) in Dr. Soetomo Hospital, Surabaya, were examined by phenotypic confirmatory test; i.e., MHT, SMA, and PBA. The results of phenotypic confirmatory test were then compared to genotypic confirmatory test, i.e., Polymerase Chain Reaction (PCR).

\section{Modified Hodge Test (MHT)}

MHT was done by streaking each loopful of bacteria colony of: isolate tested, carbapenemase positive control, and carbapenemase negative control, on Mueller Hinton Agar straight from near the meropenem
$10 \mu \mathrm{g}$ disk (Oxoid) on the center to the side of petri dish. The entire agar surface had been previously inoculated with $E$. coli ATCC®25922 of density 1x107 to $2 \times 107 \mathrm{CFU} / \mathrm{ml}$ which functions as indicator of carbapenemase production. Agar was then incubated for $18-20$ hours in $37^{\circ} \mathrm{C}$. MHT result were positive if indentations of $E$. coli ATCC@25922 colonies near the streak-line of tested isolate were seen (Fig. 1).

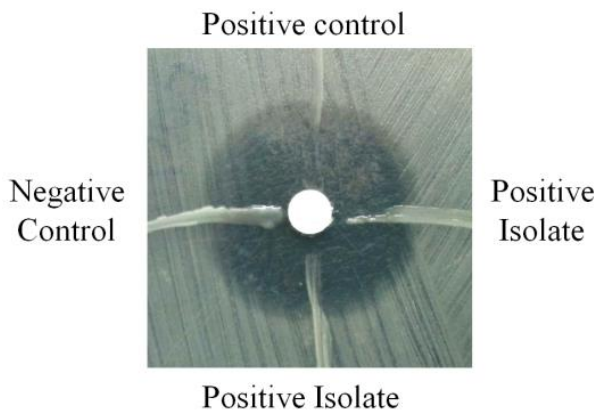

Fig. 1. Positive Modified Hodge Test, marked by indentation of Escherichia coli ATCC ${ }^{\circledR} 25922$ growth near tested isolate.

\section{Synergy test with Sodium Mercaptoacetic Acid (SMA)}

Suspension of tested isolate with $0.5 \mathrm{McFarland}$ turbidity standard was inoculated on Mueller Hinton Agar surface. SMA $3 \mathrm{mg}$ disk (Eiken Chemical Co., Ltd.) were put between meropenem $10 \mu \mathrm{g}$ disk (Oxoid) and ceftazidime $30 \mu \mathrm{g}$ disk (Oxoid) disk with 10-15 mm range of each disk. Agar was then incubated 18-20 hours in $37^{\circ} \mathrm{C}$. SMA tested positive if there were enlargement or bulging of one or both antibiotic inhibition zones toward SMA disk (Fig. 2).

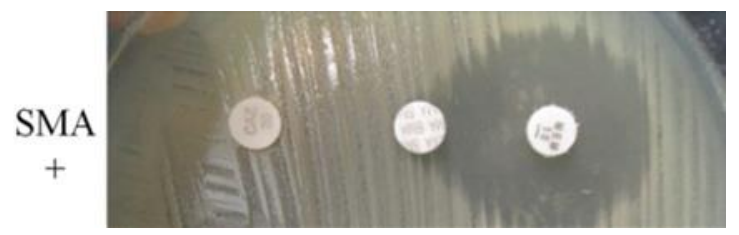

Fig. 2. Positive Sodium Mercaptoacetic Acid (SMA) test, marked by enlargement of meropenem zone of inhibition or bulging toward SMA disk.

\section{Synergy test with 3-Aminophenylboronic Acid (PBA)}

Suspension of tested isolate with 0.5 McFarland turbidity standard was inoculated on Mueller Hinton Agar surface. Two disks of meropenem $10 \mu \mathrm{g}$ (Oxoid) were put in $40 \mathrm{~mm}$ distance on agar. $300 \mu \mathrm{g}(6 \mu \mathrm{l})$ PBA was then added on one of meropenem disk. Agar were 
incubated $18-20$ hours in $37^{\circ} \mathrm{C}$. PBA tested positive if there was enlargement of antibiotic inhibition zone diameter $=5 \mathrm{~mm}$ on antibiotic that was added with PBA compared with antibiotic disk that was not added wih PBA (Fig.3).

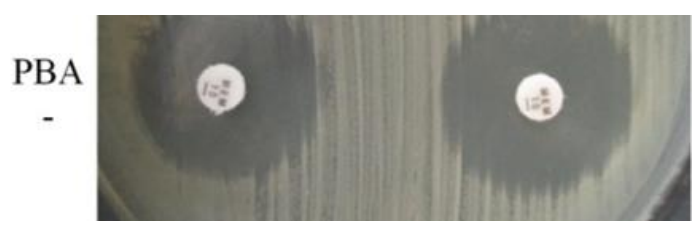

Fig. 3. Negative 3-Aminophenylboronic Acid (PBA), marked by no difference of zone of inhibitions of meropenem with and without PBA addition.

\section{Polymerase Chain Reaction (PCR)}

Multiplex PCR procedure was done using PCR kit (Thermo Fisher Scientific), primers for 7 carbapenemase genes (OXA-48, IMP1, IMP2, GES, VIM, NDM, KPC) for multiplex PCR (Sigma-Aldrich) (Fig. 4).

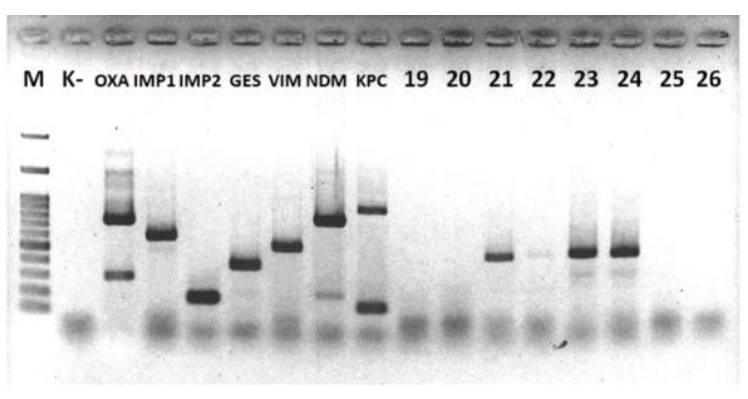

Fig. 4. PCR Result; Positive VIM gene for isolates no. 21, 22, 23, and 24. PCR: Polymerase Chain Reaction; VIM: Verona Intergron-encoded Metallo- $\beta$-lactamase.

\section{Carbapenemase classification}

Carbapenemase classification by phenotypic method based on Ambler criteria was done by matching the results of phenotypic confirmatory test with Table 1 .

Table 1. Classification of carbapenemase based on Ambler by Phenotypic Confirmatory Test

\begin{tabular}{cccc}
\hline $\begin{array}{c}\text { Carbapenemase } \\
\text { class }\end{array}$ & MHT & SMA & PBA \\
\hline A & + & - & + \\
B & $+/-$ & + & - \\
D & + & - & - \\
Not & - & - & - \\
carbapenemase & & & \\
\hline
\end{tabular}

\section{RESULTS}

Out of 30 tested isolates, 6 isolates (20.0\%) were positive for MHT, and 25 isolates $(83.3 \%)$ were positive for SMA, which indicated that most isolates produced MBL. There was no positive result for PBA test. Genotypic confirmatory test by PCR revealed that 12 isolates $(40.0 \%)$ had Verona Intergron-encoded Metallo- $\beta$-lactamase (VIM) gene, which is a member of carbapenemase class B (Table 3 ).

Table 2. Results of MHT, SMA, and PBA

\begin{tabular}{lccccc}
\hline & \multicolumn{2}{c}{ SMA } & \multicolumn{2}{c}{ PBA } & Total \\
\cline { 2 - 5 } & + & - & + & - & \\
\hline $\begin{array}{l}\text { MHT } \\
+\end{array}$ & 5 & 1 & 0 & 0 & 6 \\
MHT & 20 & 4 & 0 & 0 & 24 \\
- & 25 & 5 & 0 & 0 & 30 \\
\hline Total & 25 \\
\hline
\end{tabular}

Table 3. Percentage of results of Phenotypic Confirmatory Test and Genotypic Confirmatory Test

\begin{tabular}{cccc}
\hline Trait & Test & Positive & Negative \\
\hline Phenotypic & MHT & $20.00 \%$ & $80.00 \%$ \\
& SMA & $83.33 \%$ & $16.67 \%$ \\
& PBA & $0.00 \%$ & $100.00 \%$ \\
Genotypic & PCR & $40.00 \%$ & $60.00 \%$ \\
\hline
\end{tabular}

\section{Analysis of Modified Hodge Test (MHT) results}

Out of 12 isolates that had carbapenemase genes, there were 6 isolates that gave positive results for MHT (Table 4). There were $50.0 \%$ sensitivity and $100.0 \%$ specificity. The results of McNemar test on SPSS program were significant with $\mathrm{p}=0.031$; which means a significant difference between MHT and PCR. Symmetric measures, which comprises of Phi measurement with value of $0.612(p=0.001)$; Cramer's V $(p=0.001)$; and Kappa $(\mathrm{p}=0.001)$, revealed a match between MHT and PCR $(\mathrm{p}<0.05)$.

Table 4. Comparison of MHT to PCR results

\begin{tabular}{lccc}
\hline & \multicolumn{2}{c}{ PCR } & Total \\
\cline { 2 - 3 } & VIM + & VIM - & \\
\hline MHT + & 6 & 0 & 6 \\
MHT - & 6 & 18 & 24 \\
\hline Total & 12 & 18 & 30 \\
\hline
\end{tabular}




\section{Analysis of Sodium Mercaptoacetic Acid (SMA) results}

Out of 12 isolates with carbapenemase genes, 11 isolates gave positive results for SMA test (Table 5). There were $91.7 \%$ sensitivity and $22.2 \%$ specificity. The results of McNemar test on SPSS program were significant with $\mathrm{p}=0.01$, indicating significant difference between SMA and PCR. Symmetric measures found no match between SMA and PCR $(\mathrm{p}=0.317)$.

Table 5. Comparison of SMA to PCR results

\begin{tabular}{lccc}
\hline & \multicolumn{2}{c}{ PCR } & \multirow{2}{*}{ Total } \\
\cline { 2 - 3 } & VIM + & VIM - & \\
\hline SMA + & 11 & 14 & 25 \\
SMA - & 1 & 4 & 5 \\
\hline Total & 12 & 18 & 30 \\
\hline
\end{tabular}

\section{Analysis of MHT, SMA, and PBA combination results}

According to phenotypic confirmatory test, 26 isolates produced carbapenemase, consisting of 25 isolates that produce carbapenemase Ambler B (MHT+/-, SMA+, PBA-), and 1 isolate carbapenemase Ambler D (MHT+, SMA-, PBA-) producers. PCR results showed only 12 isolates had carbapenemase class B genes (Table 6). Comparison of carbapenemase classification by phenotypic confirmatory test and PCR were $91.7 \%$.

\section{DISCUSSION}

BD Phoenix semi-automatic system gave alert no. 399 for $E$. coli isolates that are phenotypically intermediate or resistant to carbapenems; i.e., imipenem, ertapenem, or meropenem. Isolates with alert no. 399 are considered as potential carbapenemase producers (BD 2011). The method is inaccurate for carbapenemase detection, thus it can only be used as screening method.

According to this study, MHT was a specific detection method (100\%), but not sensitive (50\%). Whereas, SMA was sensitive (91.7\%), but not specific $(22.2 \%)$. Combination of MHT, SMA, and PBA had $100 \%$ sensitivity and $22.2 \%$ specificity when compared to PCR.

Out of all isolates tested $(\mathrm{n}=30)$, only 6 isolates $(20.0 \%)$ gave positive MHT results, with $50.0 \%$ sensitivity and $100.0 \%$ specificity. MHT had few weaknesses, i.e., problem in interpretation, low specificity due to false positive results on isolates producing extendedspectrum $\beta$-lactamase (ESBL) and AmpC $\beta$-lactamase, and low sensitivity due to isolates producing Ambler B carbapenemase, such as New Delhi Metallo- $\beta$-lactamase (Thomson 2010, EUCAST 2013, Shenoy et al 2014, Bajaj et al 2016, CLSI 2016).

SMA is a cation chelator substance. SMA difference from other chelators, such as EDTA and dipicolinic acid is that SMA can bind to MBL active site specifically and render its function. EDTA inhibits MBL indirectly and unspecifically by reducing free zinc concentration on Mueller Hinton agar (Hattori et al 2013). The use of SMA with ceftazidime and meropenem is proven better in detecting MBL-producing isolates. Ceftazidime is used because all MBL-producing isolates has high resistance to ceftazidime. Meropenem is used because it has better sensitivity in detecting carbapenemase (Hattori et al 2013). In this study, SMA gave positive results for $83.3 \%$ isolates, with sensitivity of $91.7 \%$ and specificity of $22.2 \%$. Low specificity were caused by inappropirate use of gold standard in diagnostic test.

Boronic acid is the only non- $\beta$-lactam substance that can inhibit active site of serin-type carbapenemases, which are members of Ambler class A. 3Aminophenylboronic Acid (PBA) is one of boronic acid substrate that is used in laboratory. The test result is positive if zone of inhibition of disk meropenem+PBA is enlarged $=5 \mathrm{~mm}$ compared with meropenem disk without PBA (Doi et al 2008, Pournaras et al 2010, Tsakris et al 2011). In this study, there were no positive result for PBA test, which indicated no producer of carbapenemase class Ambler A had been isolated. It matches with the dominance of Ambler class B carbapenemases in South and South East Asia regions (Hsu et al 2017). False negative results may also happen if quality of reagents were below standards. In this study, quality control for PBA was not done. Although confirmation with PCR showed there was no gene encoding class A carbapenemase in the isolates. PCR method is the gold standard to confirm and classify carbapenemases. PCR gives quick results, has best sensitivity (100\%) and specificity (100\%). PCR is not a routine procedure and usually done for research and epidemiology purposes only (Galani et al 2008, Ribeiro et al 2014).

Combination of MHT, SMA, and PBA to classify carbapenemase based on Ambler had 91.7\% match with PCR. Out of 12 isolates which had VIM genes, one was phenotypically classified as Ambler class D carbapenemase producer.

PCR is not used as routine procedure to confirm carbapenemase because of vast diversity of the enzymes. Genetic variations of carbapenemases keep expanding overtime, thus carbapenemase detection by genetic 
approach would take repeated procedures and a lot of resources (Diene \& Rolain 2014).

Table 6. Comparison of phenotypic confirmatory tests (MHT, SMA, and PBA) and genotypic confirmatory test (PCR) interpretation

\begin{tabular}{lccc}
\hline Interpretation of & \multicolumn{2}{c}{ PCR } & \multirow{2}{*}{ Total } \\
\cline { 2 - 3 } Phenotypic Test & Carbapenemase + & Carbapenemase - \\
\hline Carbapenemase + & 12 & 14 & 26 \\
Carbapenemase - & 0 & 4 & 4 \\
\hline Total & 12 & 18 & 30 \\
\hline
\end{tabular}

Studies which attempt to detect carbapenemase genes in phenotypically carbapenem-resistant bacteria isolates cannot always identify carbapenemase genes in all isolates (Stuart \& Leverstein-Van Hall 2010, Karuniawati et al 2013). This is line with this study in which not all carbapenemase genes in phenotypically carbapenemase-producing organisms were identified.

Mismatch between phenotypic and genotypic confirmatory test in detecting carbapenemase can be caused by (1) carbapenemase genes in bacteria are different from the primers we used, in isolates which were confirmed as carbapenemase producers phenotypically but not genetically, or (2) another resistance mechanisms toward carbapenems, in isolates which were resistant to carbapenems but not confirmed as carbapenemaseproducers, phenotypically and genotypically.

\section{CONCLUSION}

MHT, SMA, and PBA should be interpreted as union because process of carbapenemase detection in these tests are different, thus the tests complement each other. In this study, phenotypic confirmatory test detected more MBL-producers compared with PCR. It may be caused by (1) carbapenemase genes in bacteria were different from primers used for testing, or (2) another resistance mechanisms to carbapenems. The result of this study, although should be confirmed with larger scale of research, suggests that the use of phenotypic confirmatory test to detect carbapenemase may facilitate effectiveness of antibiotic therapy in patients infected with carbapenemase-producing bacteria, thus increase survival rate and reduce length of stay in hospitals.

\section{ACKNOWLEDGMENT}

Authors would like to thank Prof. Dr. Toshiro Shirakawa, M.D., Ph.D., Shohiro Kinoshita, M.S. from Medical Faculty of Kobe University, Japan, and Dr. drh. Dadik Raharjo, M.Kes., Wahyu Setyarini, S.Si., Radita Yuniar Arizandy, S.Si., from Institute of Tropical
Diseases Universitas Airlangga Surabaya for the help in this research.

\section{REFERENCES}

Bajaj P, Singh NS, Virdi JS (2016). Escherichia coli $\beta$ lactamase: What really matters. Front. Microbiol. http://dx.doi.org/10.3389/fmicb.2016.00417

BD (2011). BD phoenix automated microbiology system user's manual. Maryland: Becton, Dickinson and Company

CLSI (2016). Performance standards for antimicrobial susceptibility testing; twenty-sixth informational supplement. Pennsylvania, Clinical and Laboratory Standards Institute

Doi Y, Potoski BA, Adams-Haduch JM, Sidjabat HE, Pasculle AW, Paterson DL (2008). Simple disk-based method for detection of Klebsiella pneumoniae Carbapenemase-type $\beta$-lactamase by use of a boronic acid compound. J. Clin. Microbiol 46, 4083-4086

EUCAST (2013). EUCAST guidelines for detection of resistance mechanisms and specific resistances of clinical and/or epidemiological importance version 1.0. Växjö, European Committee on Antimicrobial Susceptibility Testing

Galani I, Rekatsina PD, Hatzaki D, Plachouras D, Souli M, Giamarellou H (2008). Evaluation of different laboratory tests for the detection of Metallo- $\beta$ Lactamase production in Enterobacteriaceae. JAC 61, 548-553

Hattori T, Kawamura K, Arakawa Y (2013). Comparison of test methods for detecting Metallo- $\beta$-Lactamase-producing Gram-negative bacteria. Jpn. J. Infect. Dis 66, 512-518

Hsu LY, Apisarnthanarak A, Khan E, Suwantarat N, Ghafur A, Tambyah PA (2017). Carbapenem-resistant Acinetobacter baumannii and Enterobacteriaceae in South and Southeast Asia. Clin. Microbiol. Rev 30, 122

Karuniawati A, Saharman YR, Lestari DC. 2013. Detection of carbapenemase encoding genes in Enterobacteriaceae, Pseudomonas aeruginosa, and Acinetobacter baumannii isolated from patients at Intensive Care Unit Cipto Mangunkusumo Hospital in 2011. 
Acta Medica Indonesiana - The Indonesian Journal of Internal Medicine 45, 101-106

Kim SY, Hong SG, Moland ES, Thomson KS (2007). Convenient test using a combination of chelating agents for detection of Metallo- $\beta$-Lactamases in the clinical laboratory. American Society for Microbiology. J. Clin. Microbiol 45, 2798-2801

Pournaras S, Poulou A, Tsakris A. 2010. Inhibitor-based methods for the detection of KPC-carbapenemase producing Enterobacteriaceae in clinical practice by using boronic acid compounds. J. Antimicrob. Chemother 65, 1319-1321

Queenan AM, Bush K. 2007. Carbapenemases: the versatile B-lactamases. Clin. Microbiol. Rev 20, 440458

Ribeiro VB, Linhares AR, Zavascki AP, Barth AL (2014). Performance of quantification of Modified Hodge Test: an evaluation with Klebsiella pneumoniae carbapenemase-producing Enterobacteriaceae isolates. BioMed Research International

Shenoy KA, Jyothi EK, Ravikumar R (2014). Phenotypic identification \& molecular detection of blaNDM-1 gene in multidrug resistant Gram-negative bacilli in a tertiary care centre. Indian J Med Res 139, 625-631

Stuart JC, Leverstein-Van Hall MA (2010). Guideline for phenotypic screening and confirmation of carbapenemases in Enterobacteriaceae. International Journal of Antimicrobial Agents 36, 205-210
Sutandhio S, Alimsardjono L, Lusida MI (2015). Distribusi dan pola kepekaan Enterobacteriaceae dari spesimen urin di RSUD Dr. Soetomo Surabaya periode Januari - Juni 2015. Jurnal Widya Medika Surabaya 3, 53-59

Tängdén T (2012). Multidrug-resistant Escherichia coli and Klebsiella pneumoniae: treatment, selection and international spread. Acta Universitatis Upsaliensis. Digital Comprehensive Summaries of Uppsala Dissertations from the Faculty of Medicine 84072

Thomson KS (2010). Extended-Spectrum- $\beta$-Lactamase, AmpC, and carbapenemase issues. J. Clin. Microbiol 48, 1019-1025

Tsakris A, Themeli-Digalaki K, Poulou A, Vrioni G, Voulgari E, Koumaki V, Agodi A, Pournaras S, Sofianou D (2011). Comparative evaluation of combined-disk tests using different boronic acid compounds for detection of Klebsiella pneumoniae carbapenemase-producing Enterobacteriaceae clinical isolates. JCM 49, 2804-2809

Woodford N, Eastaway AT, Ford M, Leanord A, Keane C, Quayle RM, Steer JA, Zhang J, Livermore DM (2010). Comparison of BD Phoenix, Vitek 2, and MicroScan automated systems for detection and inference of mechanisms responsible for carbapenem resistance in Enterobacteriaceae. J. Clin. Microbiol 48, 2999-3002 